RLCS, Revista Latina de Comunicación Social, 72 - Pages 1,027 to 1,039

Research | DOI: 10.4185/RLCS-2017-1206en| ISSN 1138-5820 | Year 2017

How to cite this article in bibliographies / References

R Martín-Guart, H Lopez-Gonzalez, J Fernández-Cavia (2017): "Sport as an antidote against audience fragmentation. A scoping study of the most watched Spanish television shows (1989-2016)”. Revista Latina de Comunicación Social, 72, pp. 1,027 a 1,039. http://www.revistalatinacs.org/072paper/1206/56en.html

DOI: 10.4185/RLCS-2017-1206en

\title{
Sport as an antidote against audience fragmentation. A scoping study of the most watched Spanish television shows (1989-2016)
}

\author{
Ramón Martín-Guart [CV] [CORCID] [GGS] Associate professor and Ph.D. candidate in the \\ Department of Communication. Pompeu Fabra University (Spain) ramon.martin@upf.edu
}

\begin{abstract}
Hibai Lopez-Gonzalez [CV] [@ORCID] [ GGS] Postdoctoral research fellow at the International Gaming Research Unit. Nottingham Trent University (United Kingdom) hibai.lopezgonzalez@ntu.ac.uk
\end{abstract}

José Fernández-Cavia [CV] [@ORCID] [ GGS] Professor and director of the Communication Department. Pompeu Fabra University (Spain) jose.fernandez@upf.edu

\begin{abstract}
[ES] Introducción: La fragmentación de la audiencia junto con otros factores ha provocado que las cifras de audiencia disminuyan en la mayoría de las cadenas de televisión. En un nuevo contexto en el que hay que reconsiderar lo que es una buena cuota de audiencia, el contenido deportivo destaca como el último antídoto contra la fragmentación de la audiencia. Metodología: En este artículo se examina el papel del contenido deportivo en la televisión española identificando los programas de televisión más vistos cada año desde 1989 hasta 2016 y se analiza más a fondo a través de entrevistas con ocho profesionales de agencias de medios, cadenas de televisión, propietarios de derechos deportivos y patrocinadores. Resultados y conclusiones: Los resultados reflejan que los canales de televisión han capitalizado sistemáticamente el contenido deportivo premium (fundamentalmente el fútbol) para compensar los efectos de la fragmentación de la audiencia y que, ante la incertidumbre sobre los modelos comerciales de televisión, seguirán haciéndolo en un futuro próximo

[EN] Introduction: Audience fragmentation, accompanied by other factors, has caused viewing figures to drop across most television networks. In a new context where what is a good audience share needs to be reconsidered, sport content stands out as arguably the last antidote against audience fragmentation. Methodology: This paper examines the role of sport content in Spanish television by compiling the most watched television programs each year from 1989 to 2016. Sport content in television is further discussed through focused interviews with eight professionals from media
\end{abstract}


agencies, networks, media right holders and sponsors. Results and conclusions: The results suggest that networks have systematically capitalized on premium sport content (fundamentally football) to ameliorate the effects of audience fragmentation, and that, given the uncertainty concerning television business models, will continue to do so in the near future.

\section{Keywords}

[EN] Audience fragmentation; media; football; broadcasting rights; television; Spain.

\section{Contents}

[EN] 1. Introduction. 2. Fragmentation of audiences in sport. 3. Broadcasting sport in Spain. 4. Aim. 5. Method. 6. Results. 6.1. Homogenization of television content, 6.2. Fragmentation of audiences. 7. Conclusions. 8. Notes. 9. References.

Revised by Nicholas G. Charles (Academic translator and interpreter, Pompeu Fabra University and Heriot-Watt University)

\section{Introduction}

The growing number of television channels and the viewing of online television content means that audiences are increasingly split between a range of platforms. Few events manage to draw millions of viewers to television in a situation further complicated by mobile platforms that alter the time and place of access (Ling; Donner, 2009). In this untidy scenario of various consumption patterns and broadcasting windows networks appear to rely heavily on a few media contents that, despite the constant uncertainty, keep drawing wide audiences. Sport broadcasting seems to be one of these few media products (Boyle, 2014; Hutchins; Rowe, 2012).

In Spain, one phenomenon that has come to mark the audiovisual sector in recent years has been the advent of DTT in April 2010 which transformed the television business model radically owing to greater audience fragmentation in view of the larger number of channels available (Couldry; Turow, 2014; "Author", 2012). In this context, the axiom that 'a major increase in the number of free-to-air and subscription channels also entails an increase in the price of the most sought-after content' (García; Pérez; Alcolea, 2014, p. 396) occurs especially in the case of premium content such as sporting broadcast rights. This pattern has heightened with the globalization of audiovisual companies and major sporting events as they have become a highly significant business for the entertainment sector (Evens; Lefever, 2011; Giulianotti; Robertson, 2004). Spain is not an exception and Spanish channels have capitalized on the broadcasting of sporting events in order to swiftly raise their market share, albeit at a high price.

To tackle this issue, the present paper examines how television audiences have evolved in Spain over a period of 28 years (1989-2016) in order to reflect on how sport programs have managed to appeal to mass audiences on the context of a new television model characterized by fragmentation of supply and demand. The paper further elaborates on the audience fragmentation paradigm by interviewing 8 
professionals from the media, marketing and sport sector in Spain in order to assess the viability of the business model and to discuss its evolution.

\section{Fragmentation of audiences in sport}

The commodification of professional sport is one of the most highly analyzed phenomena by scholars since sporting events have become ever present in the media, constituting one of the few types of content that can appeal to millions of viewers worldwide (Giulianotti, 2005; Llopis-Goig, 2012). Slater; Tonkiss (2001) define it as a process whereby a social phenomenon becomes saleable when it had not previously been seen in this light. The effect of commodification became heightened after the 1970s when live sporting events began to take centre stage in television listings and the value of broadcast rights was rising incessantly (Parente, 1977). The process of commodification has unquestionably transformed professional sport into a global consumer product and the space devoted to it in the media is still growing with the aim of increasing audience numbers (Cleland, 2011).

Over the past two decades, the volume of information and the speed at which it is conveyed has grown at a dramatic pace, leading to what Whannel (2008) calls vortextuality, whereby the foremost news items and specifically certain super-major events tend to take the spotlight in the media to the extent that the media agenda is compressed, with other subjects disappearing or needing to draw common ground with the dominating event, that is, the vortextual event. He points out that "in the middle of a vortextual moment, cartoons, radio phone-ins, celebrity columnists, news magazines, cultural commentators, and letter pages are all drawn in. The development of a vortextual effect during a major sport event provides momentum for the building of television audiences (Whannel, 2009, p. 210). Nowadays, in a multimedia ecosystem of digital communication, the Olympic Games, the Super Bowl, Formula 1 and major soccer championships are sporting events that can create this vortextual effect (”Author", 2014).

Vortextuality is a fundamental mechanism of addressing the fragmentation of audience interests. Few media contents have the power to produce actual vortexes of information, that is, to concentrate the viewers' attention in one single focal point. Whannel (2008) argued that sport is one of the fewest media contents able to achieve that. While many contents manage to attract niche audiences for a limited period of time, sport, and particularly premium sport content, manages to gather large audiences around specific events by seducing viewers into watching television simultaneously, making it one of the last illustrations of appointment television (Haynes, 2016).

\section{Broadcasting sport in Spain}

From 1986 onwards, management of television sporting rights in Spain took a U-turn. Hitherto, the Spanish national public broadcaster Televisión Española (TVE) had exclusive broadcasting rights for the main sporting events and it assigned some of its primary position to regional channels and to Canal+, the first subscription television channel in Spain. Along these lines, the status quo held with public television broke down, causing demand to be extremely fragmented, with sporting events being the key to attaining audiences in the millions (Hutchins, 2012; Scherer; Sam, 2012). In the light of this, television channels are investing in such events, competing to attain larger audiences by offering greater variety and better quality content. 
The first channels to predict this were the private stations Cuatro and La Sexta, currently owned by Mediaset and Atresmedia, respectively, who ventured for sport as the cornerstone of their evolution. Indeed, in 2006 Cuatro purchased the rights for the FIFA World Cup and in 2008 the rights for the UEFA Euro, a policy also applied to the Spanish soccer premiership -Liga BBVA- and, more recently, the 2014 World Cup in conjunction with Telecinco. Similarly, since its inception, La Sexta has broadcast the 2006 FIFA World Cup Germany and the FIFA Club World Cup Japan 2006. From 2006 onwards, it also freely broadcast the match of the Spanish soccer premiership on Saturdays; the FIBA EuroBasket 2007 in Spain, 2009 in Poland and 2011 in Lithuania; the 2010 FIBA World Championship, hosted by Turkey; and the 2009-2011 Formula 1 championships, among other events. It also broadcast the Clásico soccer match between F.C. Barcelona and Real Madrid on December 13, 2008 making it the most widely viewed airing on La Sexta in the channel's history with an audience share according to Kantar Media [1] of 44.7\% and in excess of 8.7 million viewers. In 2007 Mediapro group purchased the rights to most Spanish soccer clubs' matches which were broadcast via its channels La Sexta and Gol Televisión. In a context where content takes center stage (“Author”, 2012), we can understand why media groups vie so fervently for the rights to such broadcasts in what certain authors have coined the "global sporting media complex" (Rowe, 2004; De-Moragas; Kennet; Ginesta, 2010).

Telecinco has been historically the only media group that do not vie for soccer rights as it considered that soccer broadcasts lacked profitability in spite of drawing in audience shares (Artero, 2007). This notwithstanding, such a policy of content and programming changed radically in 2010 when it purchased the rights to the FIFA World Cup South Africa for 50 million euros. It subsequently paid 70 million for UEFA Euro 2012 and in 2014 purchased the rights for the FIFA World Cup Brazil for 35 million euros. Nevertheless, since the Spanish side was knocked out at an early stage - contrary to expectations - interest in the 2014 World Cup plummeted along with audience figures, thus causing income from advertising to also fall to the point where Mediaset securities fell by $3.17 \%$ on the stock exchange to 8.49 euros once the Spanish squad had been eliminated. In order to break even financially, it was calculated that the Spanish team would need to reach the quarter finals. Stock market analysts concluded that income from advertising varied between 20 and 25 million euros compared to costs of 35 million euros for the rights to free-to-air coverage, bringing about a negative effect on EBITDA (gross operating profit) of between 10 and 15 million euros (BNP Paribas, 2014).

Over the course of this period, the public channel TVE was also affected by Law 8/2009, of August 28, on the financing of the Spanish Radio and Television Corporation, which removed commercial advertising from all its channels and limited the investment earmarked for purchasing the rights to broadcast sporting events to a mere $10 \%$ of its annual budget, with the exception of the Olympic Games. In this context, TVE ceased to bid for the MotoGP championship which was ultimately awarded to Mediaset for the 2010-11 season for 20 million euros each year, although it did retain the rights to the UEFA Champions League up to the 2014-15 season for 40 million euros per year, to later lose them again to Atresmedia from 2015 on.

Although soccer may appear to be at the core of the battle for sporting broadcasting rights, the major multimedia groups have begun bidding for other sporting rights such as the MotoGP championship as mentioned-, Formula 1 and basketball essentially, the bidding for which is tied in with the income expected from advertising and the audiences the events are expected to draw (Gratton; Solberg, 2007), taking into consideration other earnings stemming, for instance, from subscriptions to pay-per-view 
channels and programs. Mediapro has been characterized for bidding heavily for the rights to broadcast key sporting events, not just soccer, like Formula 1, the broadcasting rights for which it took from Telecinco in 2009 having paid some 200 million euros for the 2009-2013 period. These broadcasting rights have been changing hands to the highest bidder. In this respect, for the 2014 and 2015 seasons, the rights were awarded to Antena3 for 40 million euros each year; with good reason as Formula 1 is the second most popular sport in terms of viewing figures: based on its audience share, Formula 1 exceeded the UEFA Champions League and the UEFA Euro in 2013 with a share of $35.6 \%$ and more than 3.7 million viewers.

\section{Aim}

Given the fact that with increasing audience fragmentation major sporting events, especially soccer, are the key events that secure the attention of millions of people, the main purpose of this research is to examine the impact of sporting broadcasts on the television audience over a 28-year period.

The aim of the paper is twofold: on the one hand, to compare variations in the top television programs in Spain since 1989 in terms of average viewers, audience share and program category and link these variations to the main events taking place in the Spanish television market; and on the other hand, to relate those findings to the main trends of change perceived by professionals and scholars, anticipating potential developments in a more prospective function.

\section{Method}

In order to reach the goals, set a triangulation methodology approach was chosen combining two techniques which were carried out sequentially despite centering on the same object of study. In a first stage, data were compiled from Kantar Media and Sofres, filtering by share, audience type and channel. Viewing figures for the programs on all Spanish television channels between January 1989 and October 2016 were extracted. This entailed classifying them in terms of average viewers as a percentage, average viewers in numbers and audience share for each broadcast [2]. Lastly, they were used to draw up a summary of the most viewed programs for each year.

In a second but parallel stage a number of interviews were conducted for triangulation of data, making it possible to compare, enhance and become better acquainted with the quantitative results of the previous stage (Gillham, 2005; Mason, 2002), whilst providing a perspective on the future from the viewpoint of those interviewed (Rubin; Rubin, 2012). As Merton; Kendall (1946) state, given the prior analysis made concerning the fact of reference, a focused interview was chosen. 8 focused interviews were undertaken during the data collection process in order to inform the data analysis and guide the researchers towards more relevant questions. The interviewees were chosen based on their extensive experience on the topic under study (Lindlof; Taylor, 2011) and to benefit from a sample combining professionals from networks and media agencies. Specifically, the professional sub-sample $(\mathrm{N}=5)$ consisted of experienced managerial positions from communication groups in Spain with past or present association with television broadcasting rights for elite sporting events, including Mediaset, Atresmedia, Canal+, TV3 and Mediapro. A second group of professionals $(\mathrm{N}=3)$ included representatives from media agencies and a F.C. Barcelona sponsor. 
Questions, which were posed in a language familiar to the interviewees (Kvale, 1996; Wengraf, 2001), were the following: (1) What is your opinion about the importance of sporting programs in television schedules today?; (2) Do you think sporting programming will continue to take pole position in audience shares and viewers on free television channels over the next 5 years?; (3) Do you think sporting broadcasts, and especially soccer, will ultimately be aired solely on subscription channels?; (4) What do you think will happen with other sports?; (5) It has occasionally been published that income from advertising for the broadcast of key sporting events does not cover the prices paid by channels for the broadcasting rights: how can you explain why channels pay specific amounts for the rights when profitability is not assured?

\section{Results}

\subsection{Homogenization of television content}

By analyzing the indicators on the viewing figures for the most seen programs since 1989 in Table 1, we can identify that each year the number of viewers falls and it is increasingly difficult for a television program - specifically non-sporting events - to reach millions of viewers, on account of the fragmentation of audiences between a huge variety of channels.

The most widely viewed program in 2016 was the match of the Champions League between Real Madrid and Atletico Madrid, to which 11.6 million Spaniards tuned in with a share of $26.1 \%$. Although these are outstanding figures in the current television context, they stand well behind the audience of more than 16 million Spaniards who in 1989 watched the quiz show El precio justo (The right price) broadcast on TVE1, a historical record that no other program has managed to exceed. In 1995, another successful fiction program -Farmacia de guardia- secured 31.5\% ratings, though thenceforth soccer started to hold the top positions in the ranking with audiences that rarely fall below three million viewers, although top events such as the World Cup easily bring in more than 9 million.

Table 1. Viewing figures for the leading broadcasts from 1989 to 2016

\begin{tabular}{lllll} 
Year & Program & Air date & Channel & $\begin{array}{l}\text { Audience } \\
\text { (\%) }\end{array}$ \\
\hline 1989 & El precio justo & January 2 & TVE1 & 42.8 \\
1990 & Sábado cine & January 13 & TVE1 & 37 \\
1991 & Sesión de noche / Viva la Banda & March 5 & TVE1 & 36.4 \\
1992 & Que te den concurso & June 21 & TVE1 & 29.5 \\
1993 & $\begin{array}{l}\text { Soccer: USA World Cup Qualifiers / Spain- } \\
\text { Denmark }\end{array}$ & November 17 & TVE1 & 33.3 \\
1994 & $\begin{array}{l}\text { Soccer: 1994 FIFA World Cup USA / Spain- } \\
\text { Germany }\end{array}$ & June 21 & TVE1 & 32.4 \\
1995 & Farmacia de guardia & December 28 & Antena3 & 31.5
\end{tabular}


RLCS, Revista Latina de Comunicación Social, 72 - Pages 1,027 to 1,039 Research | DOI: 10.4185/RLCS-2017-1206en| ISSN 1138-5820 | Year 2017

\begin{tabular}{|c|c|c|c|c|}
\hline 1996 & $\begin{array}{l}\text { Soccer: UEFA Euro extra time / Spain- } \\
\text { England }\end{array}$ & June 22 & TVE1 & 29.4 \\
\hline 1997 & Soccer: King’s Cup / Barcelona-Real Madrid & January 30 & Antena3 & 32.1 \\
\hline 1998 & Champions League / Juventus-Real Madrid & May 20 & TVE1 & 34.5 \\
\hline 1999 & New Year's Eve bells & December 31 & TVE1 & 3.2 \\
\hline 2000 & $\begin{array}{l}\text { Soccer: Champions League / Real Madrid- } \\
\text { Valencia }\end{array}$ & May 24 & TVE1 & 7 \\
\hline 2001 & Soccer: Champions League / Bayern-Valencia & May 23 & TVE1 & 4.7 \\
\hline 2002 & Eurovisión "Ha llegado el momento" & May 25 & TVE1 & 6.6 \\
\hline 2003 & Eurovisión "Ha llegado el momento" & May 24 & TVE1 & 5.8 \\
\hline 2004 & Soccer: UEFA Euro / Spain-Portugal & June 20 & TVE1 & 5.1 \\
\hline 2005 & $\begin{array}{l}\text { Soccer: World Cup Qualifiers / San Marino- } \\
\text { Spain }\end{array}$ & October 12 & Antena3 & 0.6 \\
\hline 2006 & $\begin{array}{l}\text { Soccer: Champions League / Barcelona- } \\
\text { Arsenal }\end{array}$ & May 17 & TVE1 & 4.8 \\
\hline 2007 & $\begin{array}{l}\text { Soccer: UEFA Cup extra time / Español- } \\
\text { Sevilla }\end{array}$ & May 16 & TVE1 & 1 \\
\hline 2008 & Soccer: UEFA Euro final / Germany-Spain & June 29 & Cuatro & .8 \\
\hline 2009 & $\begin{array}{l}\text { Soccer: Champions League / Olympique-Real } \\
\text { Madrid }\end{array}$ & December 8 & TVE1 & 19.4 \\
\hline 2010 & Soccer: 2010 World Cup / Holland-Spain & July 11 & $\begin{array}{l}\text { Telecinc } \\
\text { o }\end{array}$ & .2 \\
\hline 2011 & Soccer: King’s Cup / Barcelona-Real Madrid & April 20 & TVE1 & 9 \\
\hline 2012 & Soccer: UEFA Euro / Portugal-Spain & June 27 & $\begin{array}{l}\text { Telecinc } \\
\text { o }\end{array}$ & 7.6 \\
\hline 2013 & Soccer: Confederations Cup / Spain-Italy & June 27 & $\begin{array}{l}\text { Telecinc } \\
\text { o }\end{array}$ & 7.4 \\
\hline 2014 & Soccer: World Cup / Spain-Chile & June 18 & $\begin{array}{l}\text { Telecinc } \\
\text { o }\end{array}$ & 9.8 \\
\hline 2015 & $\begin{array}{l}\text { Soccer: Champions League / At. Madrid-Real } \\
\text { Madrid }\end{array}$ & April 14 & TVE1 & 9.4 \\
\hline 2016 & $\begin{array}{l}\text { Soccer: Champions League / Real Madrid-At. } \\
\text { Madrid }\end{array}$ & May 28 & Antena3 & 1 \\
\hline
\end{tabular}

Source: Sofres and Kantar Media, 1989-2016. Universe: individuals aged 4 and over. Scope: Spain (mainland and Balearic Islands). Compiled by authors. 
In this respect, one of the interviewees remarked that it will be difficult for channels to find a format that would overshadow soccer, such as the talent show Operación Triunfo (Star Academy) did, the first edition of which in 2001 became one of the most widely seen programs in Spanish television history with an average of 6,895,000 spectators and an audience share of $44.2 \%$.

When questioned about the importance of sporting programs in television schedules, most interviewees considered sporting broadcasts to indeed reach a wide audience, with the added benefit for channels of reaching a new, more heterogeneous audience that would otherwise be uninterested, particularly among men who are less likely to watch television. One respondent made the following point: "since they draw in broader audiences they make it possible to reach new advertisers and sponsors, increasing income from the sale of advertising spots with larger audiences”. Somewhat contrary to this line of thinking, one respondent argued that the ability of premium sport content to reach broad audiences was an ambiguous blessing, since that broadness prevented advertisers from segmenting the audience into more focused niche markets.

Respondents were also asked whether they believed that sports programs would continue to hold pole position on free television channels and half of those questioned stated that they would, although the audience would vary depending on the participation of Spanish representatives, as witnessed with the decrease of F1 audiences after Fernando Alonso’s sporting decline.

The remainder stated that although sporting events would be the most widely viewed programs, they would be broadcast on subscription channels. This latter group argued that Spain is the only country that broadcasts soccer on free channels and that, moreover, it is not easy for free channels to guarantee profitability from such a high investment in broadcasting rights, particularly in a market where advertising investment for television has fallen by 50\% since 2007, and also in a country with a high rate of Internet piracy where people are not used to paying for content.

One respondent from a TV channel noted that subscription channels could make a profit on the investment through subscription to the channel or pay-per-view for specific content. One example is Telefónica, which included the Gol Televisión soccer package free-of-charge with its standard programming and was able to secure more than 90,000 new customers in 2009 (BNP Paribas, 2010).

\subsection{Fragmentation of audiences}

TVE1 was the leading channel in 1995 attaining a share of 27.6\%. Later in 2000 its leadership amounted to $24.5 \%$ of the pie. By 2005, Telecinco was able to lead the audience by a mere $22.3 \%$, whereas in 2015 that proportion for the leader, Telecinco again, only represented an average share of $14.8 \%$. This fragmentation or -as one interviewee otherwise described it- atomization of television audiences is something that most of those participants deemed would increase in coming years owing to changing consumer habits for television and they refer to the instance of ATAWAD, which stands for anytime, anywhere, any device, describing how people watch audiovisual content in differing contexts. In this context, sport content was viewed by most of the interviewees as a natural deterrent for audience fragmentation. One respondent defined sport shows as 'insensitive to time shifting', 
considering sport one of the last strongholds of live and communal television viewing, an idea envisaged by scholars for a long time (Hutchins; Rowe, 2012; Whannel, 2014).

Lastly, one of those interviewed considered the likelihood in future of hyper-fragmentation rather than fragmentation of the audience owing to the potential incorporation into the audiovisual industry of companies such as Facebook, Google, Amazon, Apple and Microsoft who could purchase the rights to key sporting events and broadcast them globally over their platforms. In this sense, new entrants like the ones mentioned above could potentially disrupt the media sport content economy as we know it and put into question the actual meaning of television audiences. In this regard, fragmentation evoked the conflict between large global audiences and local advertising markets.

The business model of televised sport content was a major issue for many respondents. A majority of them tended to agree that subscription-based channels (or other form of pay television) will be the norm for premium contents. They all appear to anticipate that as soon as the anti-siphoning Spanish law that forces a weekly game of soccer to be aired free is revoked, all content from Spanish Liga will be broadcast behind a paywall. One respondent, however, considered that the current model of the UEFA Champions League should be the most beneficial for both teams and broadcasters. Following this model, most of the content from the competition would only be accessible through payment while one game per week is free-to-air, working as an appetizer for the whole competition. This combined model tackles the biggest long term threat of pay television in sports: the loss of interest of an audience increasingly de-familiarized with the players and teams.

Somehow counter-intuitively, price for premium sport content has continued to grow exponentially in the past two decades while the advertisers' money paying for spots for that content has been reduced or at least, has not increased accordingly. Simply put, premium sport content is often considered to be a bad financial investment. The interviewees were asked specifically why channels continue to pay large sums for broadcasting rights without assurance of profitability. A majority mentioned that sport helps them achieve huge ratings, allowing them to secure broad coverage, and distinguishing them from the rest of the competitors. Those interviewees from audiovisual groups agreed that it is a way of avoiding the negative impact of the event being bought by a competitor.

Prestige and brand equity were among the most cited reasons why broadcasters buy sport content at a loss, which are hard to gauged variables in terms of profitability. Also, as one media marketing professional put it, '[sport content] provide a huge short-term audience boost with potential for loyalty among viewers in the medium term, making them a worthwhile investment'. Media right holders expect for sport content to have an overall impact on the network's global share of audience and not only on sport programs. Indeed, they pointed out that the advantage did not merely lie in broadcasting the sporting event but in allowing the channel to generate additional content and to make up a big part of the daily news, especially on weekends, leading to benefits for sponsors owing to greater media presence. One interviewee stated that sporting programs being among the few content types that are unaffected by time-shift meant that no one would record a soccer match or Formula 1 race to view later as this is content to be enjoyed live. 


\section{Conclusions}

This article reflects on how top sporting content, especially soccer, has become in the past decades a key aspect in the Spanish television business model. The primary goal set out at the start of this paper was to determine the impact sporting broadcasts have on television audience in Spain. After analyzing the audience indicators for the television over the last 28 years we have been able to observe that sporting events are those that reach mass audiences most easily in a system characterized by a fragmentation of the supply and demand of television. Indeed, audience of fiction programs such as series, quiz shows and movies have been losing popularity over the years. We have also illustrated how the increased range of television channels, that is, fragmentation of supply, gives rise to a natural reduction in audience shares to the point where never before has a channel been the leading one with such a low share.

This situation poses a challenge for audiovisual groups in securing the largest number of spectators possible. Knowing that the key sporting events can generate vortextuality, television channels have capitalized on the popularity of professional sport as a vital component in their programming, while the process of commodification has transformed it into a global consumer product for which channels pay broadcasting rights that are not always profitable. The interviewees justified the high price owing to the prestige lent to the channel and the ability to reach a wider audience, appealing to new advertisers and sponsors with a highly qualitative, distinguished product, thereby yielding greater advertising income.

\section{Notes}

1 Kantar Media is the research institute entrusted with measuring television audiences in Spain. The universe is formed by individuals of 4 years or over and its size is 44,444,000 individuals. With regard to the sample, the data analyzed stem from a permanent panel of 4,625 homes equipped with people meters in which 11,758 individuals representing the study subjects live. The margin of error varies between $1 \%$ and $5 \%$.

2 We consider it appropriate to set out a more in-depth definition of these concepts for greater clarity. Average viewers as a percentage is the average number of people tuned in to a program divided by the target subjects. At times, it is also represented as the program rating. Audience share is the percentage of individuals tuned in to a television channel or program over the total number of individuals watching the television at the time in question.

\section{References}

Artero, Juan-Pablo (2007): Modelos estratégicos de Telecinco (1990-2005). Madrid: Fragua. ISBN 9788470742309.

BNP Paribas (2010): Guerra del fútbol de pago: Prisa pierde mientras que Mediapro y Telefónica ganan.

https://goo.gl/60ZMlc 
BNP Paribas (2014): La eliminación de España del Mundial podría costarle a Mediaset cerca de 10 millones.

https://goo.gl/ZN2jPF

Boyle, Raymond (2014): “Television Sport in the Age of Screens and Content”. Television \& New Media, v. 15, n. 8, pp. 746-751.

http://dx.doi.org/10.1177/1527476414529167

Cleland, Jamie (2011): “The media and football supporters: a changing relationship”. Media Culture and Society, v. 33, n. 2, pp. 299-315.

http://dx.doi.org/10.1177/0163443710393866

Couldry, Nick; Turow, Joseph (2014): “Advertising, big data and the clearance of the public realm: marketers' new approaches to the content subsidy”. International Journal of Communication, v. 8, pp. 1710-1726.

http://eprints.lse.ac.uk/57944/

De-Moragas, Miquel; Kennet, Chris; Ginesta, Xavier (2010): "Football and media in Europe: A new sport paradigm for the global era”. In: Tomlinson, Alan; Young, Christopher; Holt, Richard (eds.). Sport and the Transformation of Modern Europe: States, Media and Markets 1950-2010, CRESC Series. London: Routledge, pp. 128-149. ISBN 9780415592222

Evens, Tom; Lefever, Katrien (2011): "Watching the football game: Broadcasting rights for the European digital television market”. Journal of Sport and Social Issues, v. 35, n. 1, pp. 33-49. http://dx.doi.org/10.1177/0193723510396665

García-Santamaría, José-Vicente; Pérez, María-José; Alcolea, Gema (2014): “Las nuevas plataformas televisivas en España y su influencia en el mercado”. Revista Latina de Comunicación Social, v. 69, pp. 390-417.

http://dx.doi.org/10.4185/RLCS-2014-1017

Gillham, Bill (2005): Research Interviewing. The range of techniques. Berkshire: Open University Press. ISBN 0335215866

Giulianotti, Richard (2005): "Sport spectators and the social consequences of commodification. Critical perspectives from Scottish football”. Journal of Sport and Social Issues, v. 29, n. 4, pp. 386410.

http://dx.doi.org/10.1177/0193723505280530

Giulianotti, Richard; Robertson, Roland (2004): “The globalization of football: A study in the glocalization of the 'serious life"”. The British Journal of Sociology, v. 55, n. 4, pp. 545-568. https://pdfs.semanticscholar.org/bc63/781f7f3ea32ac5b5253ec918d9c8920c6b5f.pdf

Gratton, Chris; Solberg, Harry-Arne (2007): The Economics of Sport Broadcasting. Oxon: Routledge. ISBN 9780415357807 
RLCS, Revista Latina de Comunicación Social, 72 - Pages 1,027 to 1,039 Research | DOI: 10.4185/RLCS-2017-1206en| ISSN 1138-5820 | Year 2017

Haynes, Richard (2016): BBC Sport in black and white. London: Palgrave Macmillan. ISBN 9781137454997

Hutchins, Brett (2012): "Sport on the move: The unfolding impact of mobile communications on the media sport content economy”. Journal of Sport and Social Issues, v. 20, n. 10, pp. 1-19.

http://dx.doi.org/10.1177/019372351245893

Hutchins, Brett; Rowe, David (2012): Sport beyond television. The Internet, digital media and the rise of networked media sport. New York: Routledge. ISBN 9780415734202

Kvale, Steinar (1996): Interviews. An introduction to qualitative research interviewing. London: Sage Publications. ISBN 0803958196

Lindlof, Thomas; Taylor, Bryan (2011): Qualitative communication research methods. London: Sage Publications. ISBN 9781412974738

Ling, Rich; Donner, Jonathan (2009): Mobile communication. Cambridge: Polity Press. ISBN 9780745644134

Llopis-Goig, Ramon (2012): "From 'socios' to 'hyper-consumers': an empirical examination of the impact of commodification on Spanish football fans”. Soccer \& Society, v. 13, n. 3, pp. 392-408. http://dx.doi.org/10.1080/14660970.2012.655508

Mason, Jennifer (2002): Qualitative Researching. London: Sage Publications. ISBN 9780761974284

Merton, Robert; Kendall, Patricia (1946): “The focused interview”. American Journal of Sociology, v. 51, n. 6, pp. 541-547.

http://dx.doi.org/10.1086/219886

Oltmann, Shannon (2011): “Telephone \& email interviews: using the respondents' context to determine the best interview mode”. In: Proceedings of the 2011 iConference. New York:

Association for Computing Machinery, pp. 734-735.

http://dx.doi.org/10.1145/1940761.1940889

Parente, Donald (1977): “The Interdependence of Sports and Television”. Journal of

Communication. v. 27, n. 3, pp. 128-132.

http://dx.doi.org/10.1111/j.1460-2466.1977.tb02138.x

Rowe, David (2004): Sport, Culture and the Media. The Untruly Trinity. Michigan: Open University Press. ISBN 0335210759

Rubin, Herbert; Rubin, Irene (2012): Qualitative interviewing. The art of hearing data. London: Sage Publications. ISBN 9781412978378

Scherer, Jay; Sam, Michael (2012): "Public broadcasting, sport and cultural citizenship: Sky's the limit in New Zealand”. Media Culture Society, v. 34, n. 1, pp. 101-111. 
RLCS, Revista Latina de Comunicación Social, 72 - Pages 1,027 to 1,039 Research | DOI: 10.4185/RLCS-2017-1206en| ISSN 1138-5820 | Year 2017

http://dx.doi.org/10.1177/0163443711429234

Slater, Don; Tonkiss, Fran (2001): Market Society: Markets and Modern Social Theory. Cambridge: Polity Press. ISBN 9780745620275

Wengraf, Tom (2001): Qualitative research interviewing. Biographic, narrative and semistructured methods. London: Sage Publications. ISBN 9780803975019

Whannel, Garry (2008): Culture, Politics and Sport: Blowing the Whistle, Revisited. New York: Routledge. ISBN 9780415417075

Whannel, Garry (2009): “Television and the transformation of sport”. Annals of the American Academy of Political and Social Science, v. 625, n. 1, pp. 205-218.

http://dx.doi.org/10.1177/0002716209339144

Whannel, Garry (2014): “The Paradoxical Character of Live Television Sport in the Twenty-First Century”. Television \& New Media, v. 15, n. 8, pp. 769-776.

http://dx.doi.org/10.1177/1527476414551180

How to cite this article in bibliographies / References

R Martín-Guart, H Lopez-Gonzalez, J Fernández-Cavia (2017): “Sport as an antidote against audience fragmentation. A scoping study of the most watched Spanish television shows (1989-2016)”. Revista Latina de Comunicación Social, 72, pp. 1.027 a 1.039.

http://www.revistalatinacs.org/072paper/1206/56en.html

DOI: $10.4185 /$ RLCS-2017-1206en

Article received on 24 July 2017. Accepted on 18 September. Published on 21 September 2017. 